\title{
The Influence of Human Leukocyte Antigens in Graft Versus Host Disease and Survival After Hematopoietic Stem Cell Transplantation in Pediatric Patients with Leukemia
}

\author{
Lösemili Pediyatrik Hastalarda Hematopoetik Kök Hücre Transplantasyonu \\ Sonrası Graft Versus Host Hastalığı ve Sağkalımda Insan Lökosit Antijenlerinin \\ Etkisi
}

\author{
Kürşat Özdilli1’2, (1) Fatma Savran Oğuz², (1) Sema Anak³, (1) Yeliz Öğret² , (1) Hayriye Şentürk Çiftçi², \\ Rüştü Oğuz ${ }^{4}$, (1) Mahmut Carin ${ }^{5}$ \\ ${ }^{1}$ Medipol University Faculty of Medicine, Department of Medical Biology, Istanbul, Turkey \\ ${ }^{2}$ Istanbul University, Istanbul Faculty of Medicine, Department of Medical Biology, Istanbul,Turkey \\ ${ }^{3}$ Medipol University Faculty of Medicine, Department of Pediatric Hematology, Istanbul, Turkey \\ ${ }^{4}$ Istanbul Demiroğlu Bilim University, Gayrettepe Florence Nightingale Hospital, Tissue Typing and Immunogenetic Laboratory, Istanbul, Turkey \\ ${ }^{5}$ Istinye University, Tissue Typing and Immunogenetic Laboratory, Istanbul,Turkey
}

\begin{abstract}
Objective: Hematopoietic stem cell transplantation (HSCT) is an important therapy for hematological diseases. One of the most significant complications of HSCT is graft versus host disease (GVHD), and major histocompatibility complex (MHC) is well known to affect GVHD and graft rejection. This study aimed to examine the effect of human leukocyte antigens (HLA) on the incidence of GVHD development in patients with leukemia.

Methods: The association between HLA and GVHD formation was evaluated in 57 patients with HSCT with HLA-identical sibling donors, of whom 37 were boys and 20 were girls with a mean age of 10.11 years. All patients were diagnosed with leukemia; acute myeloid leukemia $(n=33)$, acute lymphoblastic leukemia $(n=15)$, and chronic myeloid leukemia $(n=9)$. Transplantation pairs were worked for HLA-A, $-B,-C$, and -DRB1 alleles. Class I HLA antigens were investigated using Terasaki microlymphocytotoxicity, whereas class II HLA alleles with polymerase chain reaction - sequence-specific amplification method.

Results: The frequency of developing GVHD in patients with HSCT was found to be $17.5 \%(n=10)$. HLA-DRB1*04 allelic frequency [p=0.024, odds ratio (OR): 4.87] was found to be higher in patients who developed GVHD. However, the HLA-DRB1*11 allelic frequency ( $p=0.031$, OR: 0.12 ) was lower in patients who developed GVHD compared to patients who did not develop GVHD. Furthermore, HLA-B38 ( $p=0.002)$ and HLA-B41 ( $p=0.002$ ) antigens were found only in patients who developed GVHD. The frequencies of the HLA-A26 allele ( $p=0.12)$ and the HLADRB1*11 allele ( $p=0.037$, OR: 4.0) were higher in patients with relapse after HSCT; however, the frequencies of the HLA-A2 allele ( $p=0.033, O R$ : 0.19) was lower in patients who relapsed after HSCT.
\end{abstract}

Conclusion: This study assessed the relationship of HLA class with GVHD, relapse, and survival in children after HSCT in pediatric patients with leukemia.

Keywords: HLA, GVHD, leukemia, HSCT

\section{öz}

Amaç: Hematopoetik kök hücre nakli (HKHN), hematolojik hastalıklar için önemli bir tedavidir. HKHN'nin en önemli komplikasyonlarından biri, graft-versus-host hastalığıdır (GVHH) ve büyük doku uyumluluk kompleksinin (major histocompatibility complex-MHC) GVHH ve greft reddini

Address for Correspondence: Kürșat Özdilli, Medipol University, Faculty of Medicine, Department of Medical Biology, Istanbul Turkey, Istanbul University, Istanbul Faculty of Medicine, Department of Medical Biology, Istanbul, Turkey Phone: +90 542316 4576 E-mail: hayriyesenturk@gmail.com ORCID ID: orcid.org/0000-0002-7129-5024 
etkilediği iyi bilinmektedir. İnsan lökosit antijenleri (human leukocyte antigen - HLA) tipinin lösemili hastalarda GVHH insidansı üzerindeki etkisini incelemeyi amaçladık.

Gereç ve Yöntem: HLA uyumlu kardeş donörleri ile HKHN olan 57 hastada HLA ve akut, kronik GVHH oluşumu arasındaki ilişki değerlendirildi. Çalışmaya yaş ortalaması 10,11 olan 37 erkek ve 20 kız dahil edildi. Tüm hastaların tanıları; Akut myeloid lösemi ( $n=33$ ), akut lenfoblastik lösemi $(n=15)$, kronik myeloid lösemi $(n=9)$ idi. Tüm nakil kardeş çiftleri HLA-A, -B, -C, -DRB1 allelleri için tiplendirildi. Sınıf I HLA antijenleri Terasaki mikrolenfositotoksisite kullanılarak saptandı ve sınıf II HLA allelleri polimeraz zincir reaksiyonu-diziye özgü primerler (polymerase chain reaction with specific primer sequence) yöntemi ile analiz edildi.

Bulgular: HKHN uygulanan hastalar arasında GVHH insidansı \%17,5 $(n=10)$ olarak bulundu. HLA-DRB1*04 allelik frekansı [p=0,024, risk oranı (OR): 4,87] GVHH gelişen hastalarda daha yüksekti. Bununla birlikte, HLA-DRB1*11 allelik frekansı ( $p=0,031,0 R: 0,12), G V H H$ gelişen hastalarda, GVHH geliştirmeyen hastalara göre daha düşüktü. Ayrıca, HLA-B38 $(p=0,002)$ ve HLA-B41 $(p=0,002)$ antijenleri sadece GVHH gelişen hastalarda bulundu. HLA-A26 alelinin $(p=0,12)$ ve HLA-DRB1*11 alelinin $(p=0,037$, OR: 4,0) frekansları daha yüksekken, HLA-A2 allelinin frekansları $(p=0,033, O R: 0,19)$ HKHN sonrası nükseden hastalarda daha düşük olarak saptandı.

Sonuç: Bu çalışma, lösemili pediatrik hastalarda HKHN sonrası çocuklarda HLA sınıfının GVHH, relaps ve sağkalım ile ilişkisini değerlendiren çalışmadır.

Anahtar Kelimeler: HLA, GVHH, lösemi, HKHN

\section{INTRODUCTION}

The success of bone marrow transplantation and remission depends on the degree of histocompatibility of human leukocyte antigens (HLA) between the recipient and the donor in allogeneic transplantation. In a transplant, HLA and minor histocompatibility antigens from the transmitted organ or tissue are delivered to the recipient organism. Antigens that are not possessed by the recipient organism are recognized by the $T$ lymphocytes of the recipient, which results in graft rejection (1).

All patients undergoing hematopoietic stem cell transplantation (HSCT) have the risk of developing graft versus host disease (GVHD) after graft placement. The following are the involved mechanisms in GVHD pathogenesis: 1. Initial disease treatment and transplantcondition chemoradiotherapy may be a risk factor for GVHD via HLA and non-HLA molecule up-regulation, 2. HLA differences between the patient and the donor may lead to GVHD via T-cell reactivity, and 3. Cytotoxic T lymphocyte activation arising from excessive cytokine release may lead to GVHD (2). GVHD is orchestrated by immunologic response cells within the bone marrow and hematopoietic stem cells, especially $T$ lymphocytes. Even if both the recipient and the donor possess the same HLA composition, all allogeneic recipients are at risk of developing GVHD due to the existence of minor histocompatibility antigens. mHAs are polymorphic antigens that contribute independently to HLA. mHA-1 and mHA-2 antigens expressed on hematopoietic cells are recognized by alloreactive T-cells and lead to GVHD (2). Many studies showed that HLA antigens play a role in GVHD development $(3,4)$. The risk of chronic GVHD was reported to be significantly higher if the recipient and donor pairs with HLA class I allele mismatch (5). Despite the attainment of compatibility among the HLA-A, -B, and -DR alleles, GVHD is still a major complication that can result in mortality and morbidity (5).

Some studies indicated a possible relationship between GVHD and HLA antigens. The compatibility of both classes of the major histocompatibility complex (MHC) decreases the rate of mortality associated with GVHD. According to Wing and colleagues (6), the compatibility of HLA-A and HLA-B (class I) is as significant as the compatibility of the HLA-DR alleles (class II) (6).

This study aimed to examine the influence of HLA antigens on GVHD incidence between patients with leukemia who had undergone transplantation from HLA-identical siblings.

\section{METHODS}

In 57 blood samples, class I HLA antigens were investigated using Terasaki microlymphocytotoxicity, whereas class II HLA alleles were analyzed with the polymerase chain reaction - specific primer sequence (PCR-SSP) method. In the serological method, lymphocytes were isolated, and a 144-well plate containing HLA-A and HLA-B antibodies was used (7). The presence of DRB gene domains in the DNA samples was assessed with the PCR-SSP "low resolution" method using 24 primer pairs. PCR products were subjected to $2 \%$ gel electrophoresis and visualized under UV light (8). This is a retrospective study from a thesis (03.19.2003). Therefore, this study was approved by The Administrative Board of Istanbul University Institute of Health, Istanbul University, Istanbul, Turkey.

\section{Study Population}

The association between HLA antigens and the occurrence of acute and chronic GVHD was evaluated in 57 patients with HSCT having HLA-identical sibling donors, of whom 37 were boys and 20 were girls with a mean age of 10.11 years. All patients had leukemia [acute myeloid leukemia (AML) 
$(n=33)$, acute lymphoblastic leukemia (ALL) $(n=15)$, chronic myeloid leukemia $(C M L)(n=9)]$. Patients with $A M L$ were treated with busulfan and cyclophosphamide. VP16 and TBI were given to ALL patients. Patients with CML received cyclophosphamide and busulfan.

\section{Statistical Analysis}

Windows Statistical Package for the Social Sciences version 21.0 was used for statistical calculations (IBM, USA). Continuous numerical (quantitative) values were given as mean \pm standard deviation (SD) and categorical (nominal) values as a percentage (\%). The associations between HLA antigens and GVHD and relapse incidence were performed using Chi-square or Fisher's Exact test. Odds ratios (OR) were also calculated. Survival was calculated using the KaplanMeier test. Comparison of survival curves between the groups was done by long rank test. Statistical significance was accepted when the $p$-value was $<0.05$.

\section{RESULTS}

Our study group, which underwent HSCT, consists of 57 patients. Of this group, 33 (57.89\%) were diagnosed with AML, 15 with ALL (26.32), and 9 with CML (15.79\%). Thirtyseven of the patients were male and 20 were female with a mean age of 10.11 years. The patient characteristics are summarized in Table 1. Additionally, 12 (52.2\%) patients with AML, 6 (26.0\%) with ALL, and 5 (21.8\%) with CML died, whereas 21 (61.7\%) patients with AML, 9 (26.5\%) with ALL, and $4(11.8 \%)$ with CML were alive. The distribution of survival after HSCT according to the diagnosis is shown in Table 2.

Between patients who underwent HSCT, the incidence of GVHD was found to be $17.5 \%(n=10)$. The overall incidence of relapse was $23.0 \%(n=13)$ (Table 3$)$.

Table 1. Characteristic of patients

\begin{tabular}{llll}
\hline Patients & Frequency & $\%$ & Age of mean \pm SD \\
\hline $\mathrm{N}=57$ & - & - & $10.11 \pm 4.05$ \\
\hline Diagnosis & & & \\
\hline $\mathrm{AML}$ & 33 & 57.89 & $9.85 \pm 4.04$ \\
\hline $\mathrm{ALL}$ & 15 & 26.32 & $9.45 \pm 3.99$ \\
\hline $\mathrm{CML}$ & 9 & 15.79 & $10.03 \pm 4.01$ \\
\hline Sex & & & \\
\hline Female & 20 & 64.91 & $9.30 \pm 4.08$ \\
\hline Male & 37 & 35.09 & $10.54 \pm 4.02$ \\
\hline
\end{tabular}

AML: Acute myeloid leukemia, ALL: Acute lymphoblastic leukemia, CML: Chronic myeloid leukemia, SD: Standart deviation
The HLA-DRB $1 * 04$ allelic frequency $[p=0.024$, OR: $4.87,95 \%$ confidence interval (CI): 1.139-20.874] was higher in patients who developed GVHD. However, the HLA-DRB1*11 allelic frequency ( $p=0.031$, OR: $0.12,95 \% \mathrm{Cl}$ : 0.015-1.077) was lower in patients who had developed GVHD compared to patients who did not develop GVHD. Furthermore, HLA-B38 $(p=0.002)$ and HLA-B41 $(p=0.002)$ antigens were only found in patients who developed GVHD (Table 4). The frequencies of the HLA-A26 antigen ( $p=0.012$, OR: $7.0095 \% \mathrm{Cl}: 1.300$ 37.400) and the HLA-DRB1*11 allele ( $p=0.037$, OR: $4.0095 \%$ $\mathrm{Cl}$ : 1.030-15.400) were higher, whereas that of the HLA-A2 antigen ( $p=0.033$, OR: $0.19,95 \% \mathrm{Cl}: 0.038-0.970$ ) was lower in patients with relapsed after HSCT. This study revealed that the HLA-B62 allele ( $p=0.005$, OR: $0.80,95 \% \mathrm{Cl}: 0.600-$ 1.070) was only found in patients who had relapsed after HSCT (Table 4). Our study revealed that the survival rate after HSCT ranged from 1 to 144 months, with a five-year survival rate of $57.4 \%$. The survival rate among the 34 living patients ranged from 12 to 144 months, and that among the 23 patients who died after HSCT ranged from 1 to 60 months (Figure 1a). The five-year survival rate in girls was $f 62 \%$ and that in boys was 59\% (Figure 1b). Twenty-one of the 33 patients with AML survived, and five-year survival was $63 \%$.

Moreover, 9 out of 15 patients with ALL survived, and their five-year survival rate was $60 \%$. Additionally, 4 out of 9 patients with $\mathrm{CML}$ survived, and their five-year survival rate was $37 \%$ (Figure 1c). The five-year survival rate of patients who developed GVHD was $48 \%$ and that in patients who had not developed GVHD was 58\% (Figure 1d).

\section{DISCUSSION}

Conventional chemotherapy results in a good prognosis by curing $70 \%$ of pediatric patients with a diagnosis of low-risk

Table 2. Survival rates of patients after HSCT

\begin{tabular}{llll}
\hline Survival $(\mathbf{n}=57)$ & Diagnosis & $\mathbf{n}$ & Frequency \% \\
\hline \multirow{3}{*}{ Yes $(n=34)$} & AML & 21 & 61.7 \\
\cline { 2 - 4 } & ALL & 9 & 26.5 \\
\hline & CML & 4 & 11.8 \\
\hline & TOTAL & 34 & 100 \\
\hline \multirow{3}{*}{ No $(n=23)$} & AML & 12 & 52.2 \\
\hline & ALL & 6 & 26.0 \\
\hline & CML & 5 & 21.8 \\
\hline & TOTAL & 23 & 100 \\
\hline
\end{tabular}

HSCT: Hematopoietic stem cell transplantation, AML: Acute myeloid leukemia, ALL: Acute lymphoblastic leukemia, CML: Chronic myeloid leukemia 

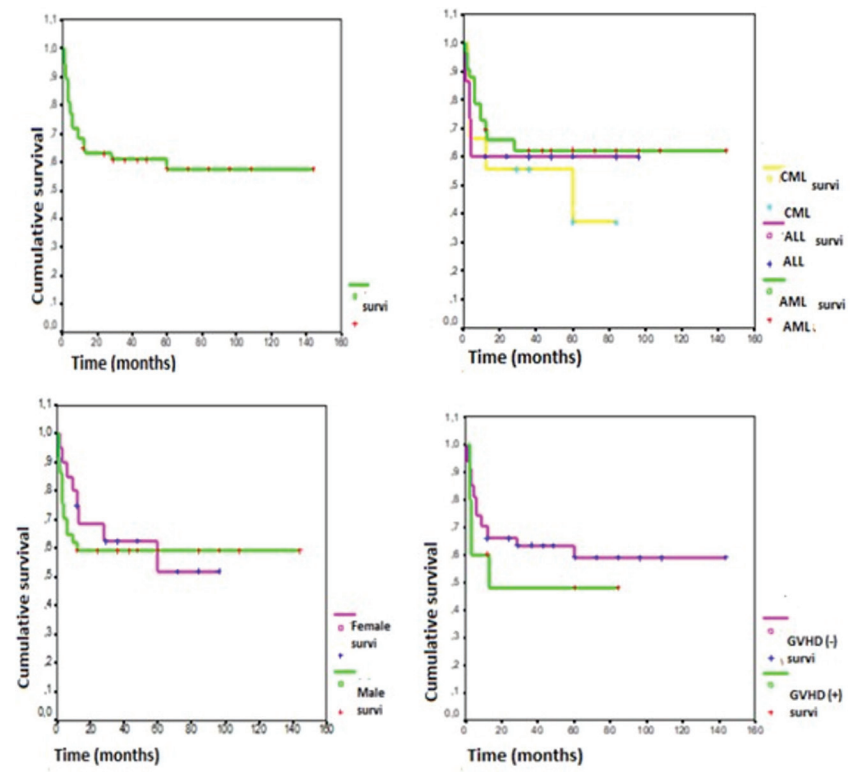

Figure 1. a. The survival rate, b. The survival rate according to diagnosis, c. The survival rate according to sex, d. The survival rate according to GVHD

GVHD: Graft versus host disease, AML: Acute myeloid leukemia, ALL: Acute lymphoblastic leukemia, CML: Chronic myeloid leukemia

ALL. In patients with high-risk ALL (chromosome anomaly, treatment responsiveness, and relapse), allogeneic SCT is a good therapeutic option (9). HSCT is an important therapy for hematological diseases $(10,11)$. One of the most significant complications of HSCT is GVHD, and MHC is known to affect GVHD and graft rejection $(12,13)$.

A study performed in 751 patients with CML who are transplanted from HLA-identical siblings revealed that HLA-A3 antigen was a risk for GVHD, whereas DR1 allele was shown to be protective against GVHD (2). A study by Kekik et al. (14) which was conducted in 108 adult patients who were transplanted with allogeneic bone marrow, reported that the HLA-A24 allele had a protective role against GVHD development. Kim et al. (15), who studied 389 patients in Korea, determined the acute GVDH rate after attention bias modification training (ABMT) as $34.8 \%$ and the chronic GVHD rate after ABMT as $21.2 \%$. Additionally, patients with acute GVHD had a high frequency of HLA-B61 and HLA-Cw3; however, patients with chronic GVHD had a high frequency of HLA-B54. Another study revealed that the presence of the HLA-A10 (which is in the sub-group of HLA-A25 and HLA-A26) and HLA-B7 antigens were found to increase the risk of acute GVHD, whereas an increased frequency of HLA-B27 decreased the incidence of chronic GVHD (16). The number of patients who developed GVHD after HSCT $(n=10)$ is low, thus previous research is insufficient on this
Table 3. GVHD and relapse rates after the HSCT

\begin{tabular}{|c|c|c|c|}
\hline GVHD (+) $(n=10)$, & $17.5 \%$ & GVHD (-) (n=47) & $82.5 \%$ \\
\hline Survival & Frequency \% & Survival & Frequency \% \\
\hline Yes $(n=5)$ & $(8.75 \%)^{\star}$ & Yes $(n=29)$ & $(50.91 \%)^{*}$ \\
\hline No $(n=5)$ & $(8.75 \%)^{\star}$ & No $(n=18)$ & $(31.59 \%)^{\star}$ \\
\hline \multicolumn{4}{|l|}{ Sex } \\
\hline Female $(n=5)$ & $(8.75 \%)^{\star}$ & $\begin{array}{l}\text { Female } \\
(n=15)\end{array}$ & $(26.32 \%)^{\star}$ \\
\hline Male $(n=5)$ & $(8.75 \%)^{\star}$ & Male $(n=32)$ & $(56.18 \%)^{\star}$ \\
\hline \multicolumn{4}{|l|}{ Diagnosis } \\
\hline $\operatorname{ALL}(n=2)$ & $(3.5 \%)^{\star}$ & $\operatorname{ALL}(n=13)$ & $(22.82 \%)^{\star}$ \\
\hline AML $(n=4)$ & $(7.0 \%)^{\star}$ & AML $(n=29)$ & $(50.90 \%)^{\star}$ \\
\hline $\mathrm{CML}(\mathrm{n}=4)$ & $(7.0 \%)^{\star}$ & $\mathrm{CML}(\mathrm{n}=5)$ & $(8.78 \%)^{\star}$ \\
\hline \multicolumn{2}{|c|}{ Relapse $(+)(n=13), 23.0 \%$} & \multicolumn{2}{|c|}{ Relapse $(-)(n=44), 77.0 \%$} \\
\hline Survival & Frequency \% & Survival & Frequency \% \\
\hline Yes $(n=3)$ & $(5.31 \%)^{\star}$ & Yes $(n=31)$ & $(54.25 \%)^{\star}$ \\
\hline No $(n=10)$ & $(17.69 \%)^{\star}$ & No $(n=13)$ & $(22.75 \%)^{\star}$ \\
\hline \multicolumn{4}{|l|}{ Sex } \\
\hline Female $(n=5)$ & $(8.85 \%)^{\star}$ & $\begin{array}{l}\text { Female } \\
(n=15)\end{array}$ & $(26.25 \%)^{\star}$ \\
\hline Male $(n=8)$ & $(14.15 \%)^{\star}$ & Male $(n=29)$ & $(50.75 \%)^{\star}$ \\
\hline \multicolumn{4}{|l|}{ Diagnosis } \\
\hline $\operatorname{ALL}(n=3)$ & $(5.31 \%)^{\star}$ & $\operatorname{ALL}(n=12)$ & $(21.00 \%)^{\star}$ \\
\hline AML $(n=7)$ & $(12.38 \%)^{\star}$ & AML $(n=26)$ & $(45.50 \%)^{\star}$ \\
\hline $\mathrm{CML}(\mathrm{n}=3)$ & $(5.31 \%)^{\star}$ & $\mathrm{CML}(\mathrm{n}=6)$ & $(10.50 \%)^{*}$ \\
\hline
\end{tabular}

*An in-group seen percentage, GVHD: Graft versus host disease, HSCT: Hematopoietic stem cell transplantation, AML: Acute myeloid leukemia, ALL: Acute lymphoblastic leukemia, CML: Chronic myeloid leukemia

subject. Cardozo and colleagues, who studied 179 patients, reported that acute GVHD is positively associated with HLA-A10, HLA-A26, B55, DRB1*15, and DQB1*05, whereas HLA-B16 is higher in patients without acute GVHD. Ivana and colleagues, who studied 96 patients, determined the acute GVDH rate after HSCT as $31.3 \%$ and the chronic GVHD rate after $\mathrm{HSCT}$ as $26.0 \%$. Another study in patients carrying the HLA-A*01, DRB1*03, and DQB1*03 alleles revealed a statistically significantly lower ratio of acute GVHD, as well as the relationship with a higher ratio of chronic GVHD in patients carrying the HLA-DQB1*06 allele (18).

This study compared patients concerning the HLA haplotype, class I HLA-B antigens, namely HLA-B38 and HLA-B41, were not identified in patients who had not developed GVHD. Meanwhile, the frequencies of the class II HLA-DRB1 alleles, HLA-DRB1*04, and HLA-DRB1*11 were 
Table 4. The relationship between HLA and GVHD, relapse

\begin{tabular}{|c|c|c|c|c|c|c|}
\hline & GVHD (+) n=10 & & GVHD (-) n=47 & & $p$ & OR Cl\% \\
\hline HLA & & $\%$ & & $\%$ & & \\
\hline B38 & 2 & 20 & 0 & 0 & 0.002 & $0.80(0.587-1.091)$ \\
\hline B41 & 2 & 20 & 0 & 0 & 0.002 & $0.80(0.587-1.091)$ \\
\hline DRB1*04 & 5 & 50 & 8 & 17 & 0.024 & $4.87(1.139-20.874)$ \\
\hline \multirow[t]{3}{*}{$\mathrm{DRB} 1 * 11$} & 1 & 10 & 22 & 47 & 0.031 & $0.12(0.015-1.077)$ \\
\hline & Relapse $(+) n=13$ & & Relapse (-) n=44 & & $\mathrm{p}$ & $\mathrm{OR}, \mathrm{Cl} \%$ \\
\hline & & $\%$ & & $\%$ & & \\
\hline $\mathrm{A} 2$ & 2 & 17 & 23 & 51 & 0.033 & $0.19(0.038-0.970)$ \\
\hline A26 & 4 & 33 & 3 & 7 & 0.012 & $7.00(1.300-37.400)$ \\
\hline B62 & 2 & 17 & 0 & 0 & 0.005 & $0.80(0.600-1.070)$ \\
\hline DRB1*11 & 8 & 67 & 15 & 33 & 0.037 & $4.00(1.030-15.400)$ \\
\hline
\end{tabular}

higher and lower, respectively, in patients who developed GVHD compared to patients who did not develop GVHD.

Among 57 patients, 13 had relapsed (23.0\%). The relapse frequency was higher in patients with AML (7/13). The comparison of patients with and without relapse revealed that, in patients with $A M L$, the HLA-A26 frequency was higher but the HLA-A2 frequency was lower, which corroborates the idea of Von Fliedner et al. (19) that the presence of HLA-A2 is a sign of a good prognosis. Our study revealed that the HLA-DRB1*11 allelic frequency was higher in patients with relapsed $\mathrm{HSCT}$, similar to previous studies that showed that the allelic frequency of this HLA is higher in patients with AML (19). Thus, a high frequency of the HLA-DRB1*11 allele could be a sign of a poor prognosis.

The rate of the HLA-A24 antigen was higher in patients who survived, whereas the frequencies of the HLA-A26 and HLA-B8 antigens were higher in patients who died after HSCT. HLA-A26 could be assessed as a bad prognosis factor because the HLA-A10 antigen increased the risk of acute GVHD and that the five-year survival rate of patients who developed GVHD is poor compared to that of patients who did not develop GVHD (16).

\section{CONCLUSION}

This study is very important since it evaluates the relationship of HLA class with GVHD, recurrence, and survival in children after HSCT. This study incorporated 57 cases from the genetic pool of the Turkish population, but larger studies must be performed in the future.

\section{ETHICS}

Ethics Committee Approval: This is a retrospective study from a thesis (03.19.2003). Therefore, this study was approved by The Administrative Board of Istanbul University Institute of Health, Istanbul University, Istanbul, Turkey.

Informed Consent: This is a retrospective study.

\section{Authorship Contributions}

Surgical and Medical Practices: K.Ö., S.A., Concept: K.Ö., F.S.O., Design: K.Ö., H.Ş.Ç., Data Collection or Processing: K.Ö., F.S.O., Analysis or Interpretation: K.Ö., F.S.O., Y.Ö., H.Ş.Ç., M.C., Literature Search: K.Ö., F.S.O., R.O., Writing: K.Ö., F.S.O., H.Ş.Ç.

Conflict of Interest: No conflict of interest was declared by the authors.

Financial Disclosure: The authors declared that this study received no financial support.

\section{REFERENCES}

1. Roitt IM. Essential Immunology. London: Blackwell Science; 1997.

2. Clark RE, Hermans J, Madrigal A, Nachbaur D, Kropshofer G, Gratwohl A, et al. HLA-A3 increases and HLA-DR1 decreases the risk of acute graft-versus-host disease after HLA-matched sibling bone marrow transplantation for chronic myelogenous leukaemia. Br J Haematol 2001;114:36-41.

3. Askonas BA, Openshaw PJ. MHC and antijen presentation. Immunol Today 1989;10:396-7.

4. Long EO. Processing requirements for presentation of antigens to T lymphocytes. Curr Opin Immunol 1988;1:98-102.

5. Greinix HT, Faé I, Schneider B, Rosenmayr A, Mitterschiffthaler A, Pelzmann B, et al. Impact of HLA class I high-resolution mismatches on chronic graft-versus-host disease and survival of patients given hematopoietic stem cell grafts from unrelated donors. Bone Marrow Transplant 2005;35:57-62. 
6. Leung WH, Turner V, Richardson SL, Benaim E, Hale G, Horwitz EM, et al. Effect of HLA class I or class II incompatibility in pediatric marrow transplantation from unrelated and related donors. Human Immunol 2001;62:399-407.

7. Terasaki PI, McClelland JD. Microdroplet assay of human serum cytotoxins. Nature 1964;204:998-1000.

8. Olerup $\mathrm{O}$, Zetterquist $\mathrm{H}$. HLA-DR typing by PCR amplification with sequence-specific primers (PCR-SSP) in 2 hours: an alternative to serological DR typing in clinical practice including donorrecipient matching in cadaveric transplantation. Tissue Antigens 1992;39:225-35.

9. Jernberg AG, Remberger M, Ringden $O$, Winiarski J. Risk factors in pediatric stem cell transplantation for leukemia. Pediatr Transplant 2004:8:464-74.

10. Hoffbrand AV, Pettit JE. Acute Leukemias, Oxford, Blackwell Scientific Publications; 1993.

11. Lanzkowsky P. Bone Marrow Transplantation, New York: Churchill Livingstone; 1995.

12. Roitt I, Brostff J, Male D. Immunology. London: Mosby-Year Book; 1993.

13. Trowsdale J. Organization of the human MHC. In: Svejgaard A, Buus Soren, Fugger L, editors. HLA and Disease-the Molecular Basis. Alfred Benzon Symposium 40, Copenhagen; 1997. p. 21-32.

14. Kekik C, Besisik SK, Seyhun Y, Oguz FS, Sargin D, Carin MN. Relationship Between HLA Tissue Type, CMV Infection, and Acute
Graft-vs-Host Disease After Allogeneic Hematopoietic Stem Cell Transplantation: Single-Center Experience. Transplant Proc 2009:41:3859-62.

15. Kim HJ, Park SJ, Im HW, Kim DW, Min WS, Kim HK, et al. The association of HLA antigen and GVHD in allogeneic hemopoietic stem cell transplantation with histocompatible sibling donor: a single-center experience in Korea. Int J Hematol 2002;76:267-71.

16. Remberger $M$, Persson $U$, Hauzenberger $D$, Ringden $O$. An association between human leucocyte antigen alleles and acute and chronic graft-versus-host disease after allogeneic haematopoietic stem cell transplantation. Br J Haematol 2002;119:751-9.

17. Cardozo DM, Lieber SR, Marques SB, Aranha FJ, Vigorito AC, Souza $C A$, et al. Association between human leukocyte antigens and graftversus-host diseases occurrence after allogenic hematopoietic stem cell transplantation. Sao Paula Med J 2012;130:219-24.

18. Ivana S, Bojtarova E, Kovacova M, Kluckova K, Kusikova M, Mistrik $M$, et al. Individual HLA alleles and risk of graft-versus-host diseases after haematopoietic stem cell transplantation from HLA-identical siblings. Biologia 2020;75:2045-52.

19. Von Fliedner VE, Sultan Khan Z, Jeannet M. HLA-A and HLA-B antigens in acute leukemia: A2--B12 phenotypes correlate with longer survival in acute myelogenous leukemia. Acta Haematol $1981 ; 65: 73-8$ 